\title{
Modelling of nitrogen turnover and leaching in Saxony
}

\author{
M. Gebel ${ }^{1}$, S. Halbfaß ${ }^{1}$, S. Bürger ${ }^{1}$, H. Friese ${ }^{2}$, and S. Naumann ${ }^{2}$ \\ ${ }^{1}$ Gesellschaft für Angewandte Landschaftsforschung (GALF) bR, Dresden, Germany \\ ${ }^{2}$ Saxon State Agency of the Environment, Agriculture and Geology, Dresden, Germany
}

Received: 19 January 2010 - Revised: 22 May 2010 - Accepted: 31 May 2010 - Published: 9 December 2010

\begin{abstract}
From 2005 to 2009 we modelled the input of nitrogen and phosphorus in waters in the area of the Federal State of Saxony (Germany). The model results are an important component in elucidating the present situation of nutrient loads in groundwater and surface water as well as its future development. The present contribution focuses on the modelling of diffuse nitrogen leaching on arable land. Processes of mobilization and immobilization of nitrogen are included in the modelling. They will be estimated as induced by the respective types of fruit, management practices and local conditions. Source areas can be derived using the relationship of nitrogen sources (mobilization, deposition) and sinks (immobilization, denitrification) on the regional scale.
\end{abstract}

\section{Introduction}

The intensification of the nitrogen cycle in the last decades caused an increase in environmental pollution, making necessary management strategies on the local as well as on the regional scale (UBA, 2008). According to the Umweltbundesamt of Germany we should strive for a global, multimedial and integrative point of view to solve the nitrogen problem, which is even relevant in mid european soil and water systems. Modelling diffuse nitrogen input in waters we have to reflect nitrogen transfers in the soil matrix as well as in the groundwater in addition to the consideration of input and output parameters of nitrogen.

The nitrogen balance can be computed in a simplified way as the result of inputs and outputs being done on meso- or macroscale by different modelling tools (e.g. Behrendt et al., 2002; Schoumans et al., 2009). The consideration of nitrogen turnover is mainly included on the micro- to mesoscale

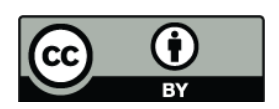

Correspondence to: M. Gebel (gebel@galf-dresden.de) modelling with a more detailed site specific view (e.g. Brisson et al., 1998; Franko et al., 1995; Kersebaum, 2006; Lam et al., 2009). In the present contribution a methodology to consider nitrogen turnover on arable land is introduced, which is also applicable in macroscale computation as part of the STOFFBILANZ software. Processes of mobilization and immobilization are estimated as induced by the respective regional conditions, types of fruit and management practices. Thus the calculated nitrogen leaching on arable land depends on the parameters of input and output as well as on the intensity of nitrogen turnover. We used this methodology in the framework of our investigations "Mapping of nutrient inputs into surface waters in Saxony (Germany)", supported by the water authorities of Saxony (Saxon State Agency of the Environment, Agriculture and Geology), as shown below.

\section{A survey to the nitrogen modelling methodology}

In the framework of the "Mapping of nutrient inputs in surface waters in Saxony (Germany)", we quantified nitrogen, phosphorus and sediment inputs in the catchment areas, using the WebGIS based model STOFFBILANZ. A detailed description of methodologies, parameters, involved datasets and results is presented in detail in Halbfaß et al. (2009). A survey to the methodology of nitrogen modelling is given by Fig. 1 .

Nitrate- $\mathrm{N}$ being readily soluable in water is extremly apt to be washed out because of its high mobility. The $\mathrm{N}$ leaching from the rooted soil matrix is generated via the different runoff components (see Gebel et al., 2009). Nitrate emissions being detectable in surface waters have been reduced by denitrification during the runoff passage in the groundwater system. The nitrate loss by denitrification in the upper aquifer (groundwater path) is computed using the residence time of groundwater and the half-value time of denitrification (see Gebel et al., 2009; Uhlig et al., 2010; Wendland, 1992; Kunkel and Wendland, 1997). Particle bound transfers of nitrogen, which are generally of minor

Published by Copernicus Publications on behalf of the European Geosciences Union. 


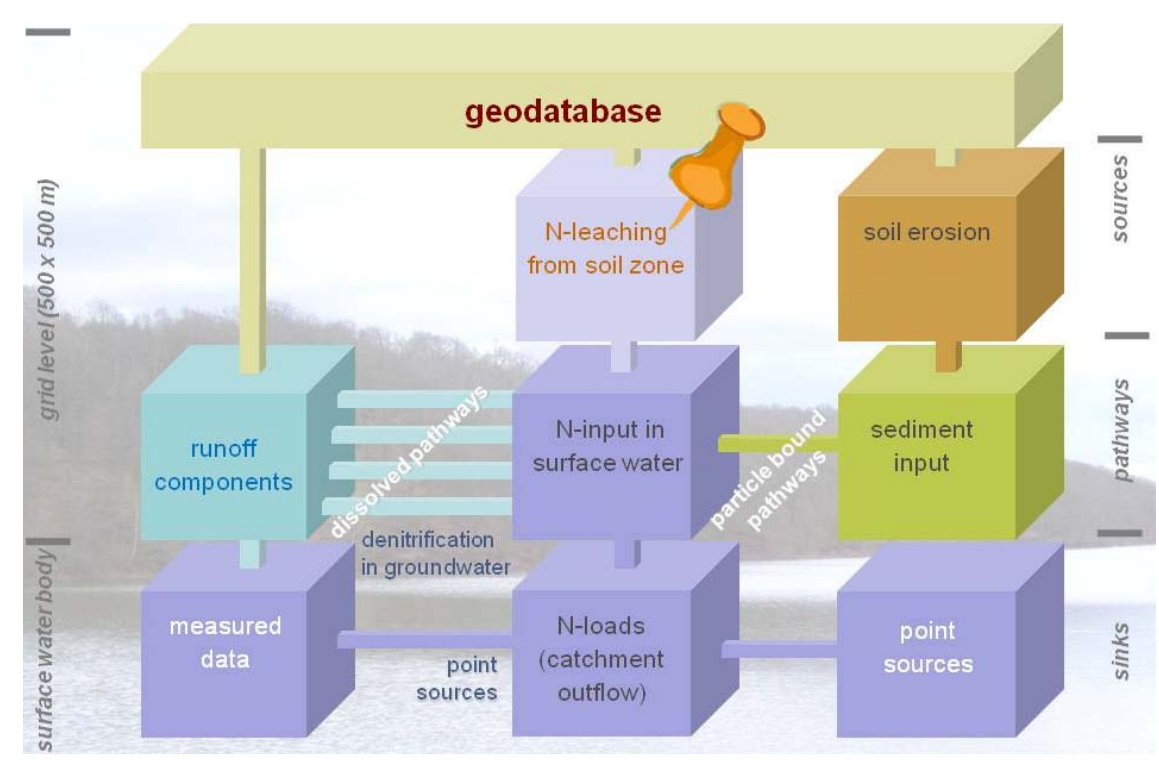

Fig. 1. Flowchart of the STOFFBILANZ.i modelling of diffuse N-inputs.

importance, and point related loadings are calculated in addition (see Gebel et al., 2009). At last we have to consider nitrogen retention in surface waters, described in detail in Halbfaß et al. (2010). In order to validate the modelling we compared our results with measured values at catchment outlets (time period from 2000 to 2005, 36 gauging stations). We got a good relationship between modelled and measured nitrogen loadings $\left(r^{2}=0.85\right)$. Four supplemental gauging stations, corresponding to larger watersheds, were excluded, in order to avoid a statistical overweight due to high emissions and loadings. However we used these stations to calibrate the modelling $\left(r^{2}=0.90\right)$ before we started the validation procedure.

\section{Calculation of nitrogen leaching on arable land}

Calculating the nitrogen leaching from the soil zone as part of the modelling, we make a division between parameters of nitrogen input, output and turnover (see Fig. 2). In the STOFFBILANZ model the processes of turnover are included for cropland using indicators of mineralization and immobilization. In the framework of the development of the model STOFFBILANZ_BW in cooperation with the agricultural authorities of the federal state of BadenWürttemberg (LTZ Augustenberg, Finck et al., 2008), we modified the methodology to derive mineralization from the organic soil matrix (humus) based on the Henin and Dupuis concept (1945). Nitrogen mobilization is calculated according to Mary and Guérif (1994) and Meynard et al. (1996), considering the content of humus, the C:N-ratio, the content of clay, lime and skeleton, the average annual temperature and the fruit type specific management practice (Fig. 3). Thus we get a differentiation including variabilities of soil texture and soil type specifications of mineralization from humus in an adequate way. Mobilizations resulting from the recent year practice (e.g. mobilization of crop residues) are not included in this part of the modelling. They are computed in addition, but not focused on in this contribution (see Gebel et al., 2009).

First, we have to determine the organic nitrogen content in topsoil $\mathrm{N}_{\text {org }}\left[\mathrm{kg} \mathrm{ha}^{-1}\right]$ using the humus content $c_{\text {humus }}[\%]$, raw density SBD $\left[\mathrm{g} \mathrm{cm}^{-3}\right]$ and $\mathrm{C}: \mathrm{N}$ ratio in topsoil (Mary and Guérif, 1994; Meynard et al., 1996):

$\mathrm{N}_{\text {org }}=\frac{c_{\text {humus }} \cdot \mathrm{SBD} \cdot 3 \cdot 10000}{1.72 \cdot \frac{C}{N}}$

The coefficient $K_{2}$ is calculated by the content of clay $c_{\text {clay }}$ and lime $c_{\text {lime }}$ in the topsoil [\%] and the average annual temperature $T_{\text {avg }}\left[{ }^{\circ} \mathrm{C}\right]$ via the coefficient $f_{t}$. The intensity of farm manure use and the frequency of an export of crop residues is taken into account for each type of fruit via the coefficient $f_{\mathrm{s}}$ to characterize the cultivation system (Table 1, according to Mary and Guérif, 1994; Meynard et al., 1996):

$$
\begin{aligned}
& K_{2}=\frac{1200 \cdot f_{\mathrm{s}} \cdot f_{t}}{\left(c_{\text {clay }} \cdot 10+200\right) \cdot\left(0.3 \cdot c_{\text {lim } e} \cdot 10+200\right)} \\
& f_{t}=0.15 \cdot T_{\text {avg }}-0.5
\end{aligned}
$$

The nitrogen mineralization $\left[\mathrm{kg} \mathrm{ha}^{-1} \mathrm{yr}^{-1}\right]$ from the organic soil matrix $\mathbf{M}_{\text {soil }}$ is determined as follows considering $\mathrm{N}_{\text {org }}$, the coefficient $K_{2}$ and the content of skeleton $c_{\mathrm{sk}}$ in the topsoil [\%]:

$\mathbf{M}_{\text {soil }}=N_{\text {org }} \cdot K_{2} \cdot 1.3 \cdot\left(1-\frac{c_{\text {sk }}}{100}\right)$

The calculation of the immobilization terms, input terms and output terms are explained in Gebel et al. (2009) in 


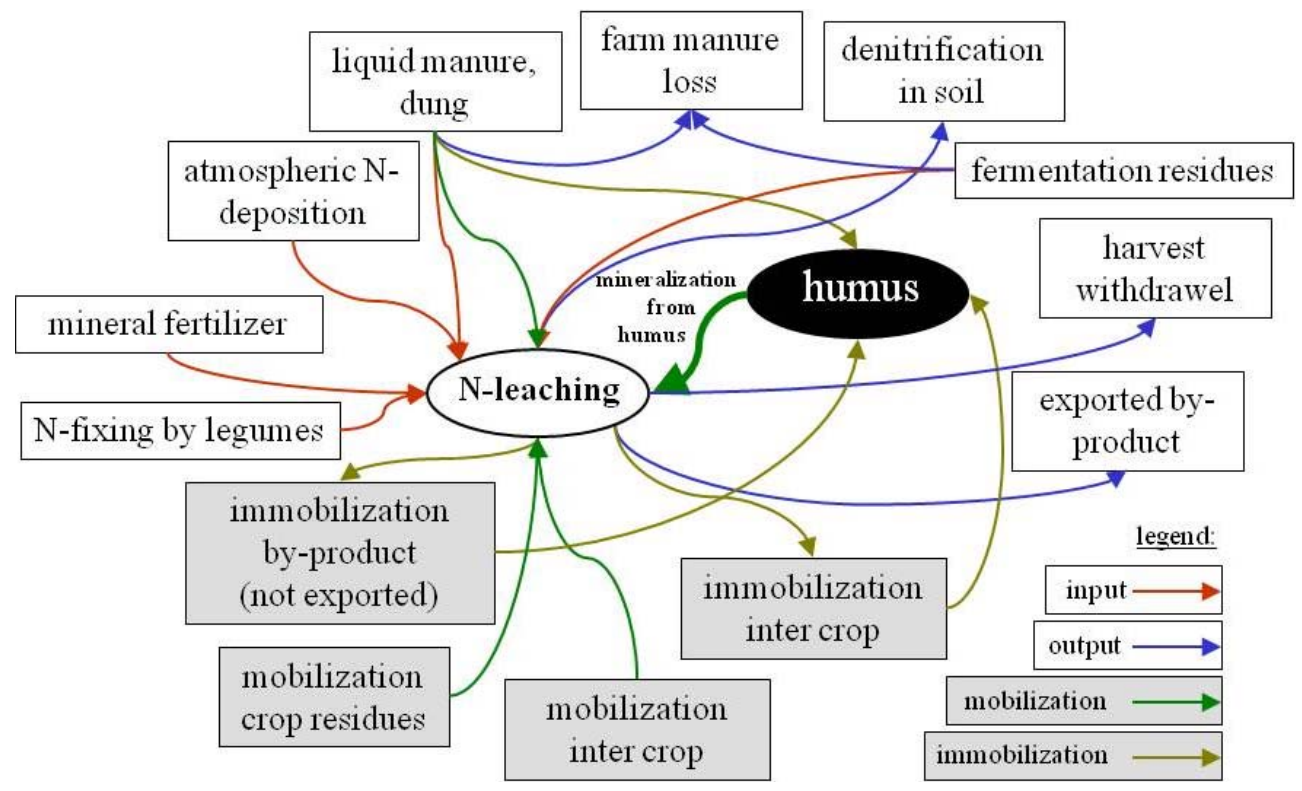

Fig. 2. Components of the N-balance on arable land.

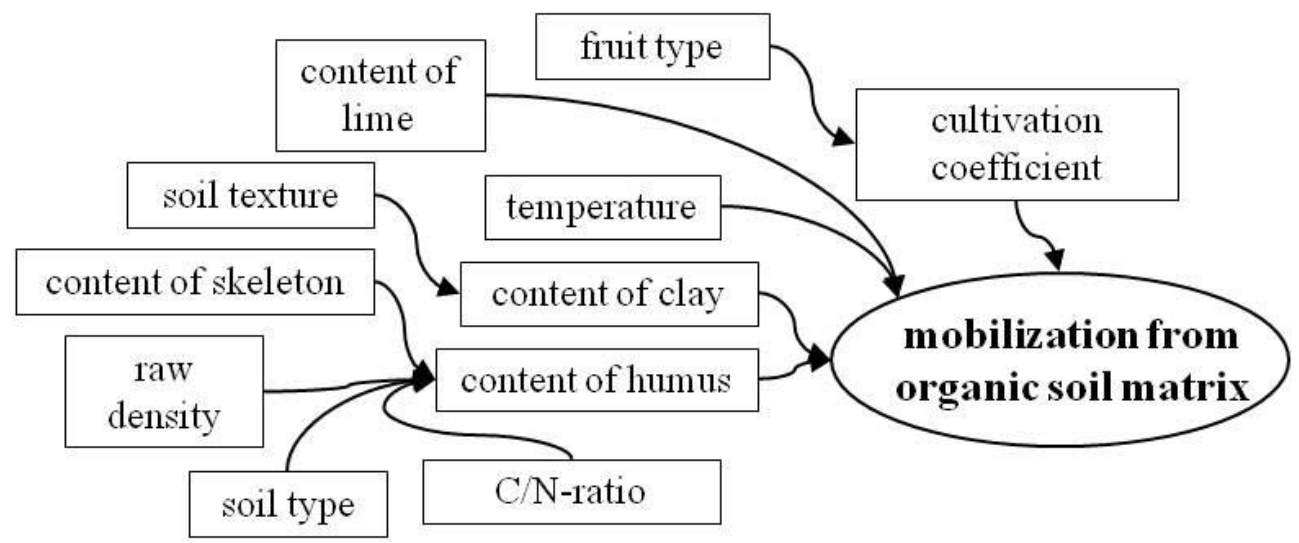

Fig. 3. Derivation of mineralization rates from the organic soil matrix on arable land.

Table 1. Definition of the coefficient $f_{\mathrm{s}}$ to characterize the cultivation practice.

\begin{tabular}{lcccc}
\hline \multirow{2}{*}{$\begin{array}{l}\text { Crop residues } \\
\text { being exported }\end{array}$} & \multicolumn{4}{c}{ Frequency of farm manure } \\
\cline { 2 - 5 } & > every 10 years & every 5-10 years & every 3-5 years & < every 3 years \\
\hline ... always & 0.8 & 0.9 & 1.0 & 1.1 \\
$\ldots$ sometimes & 0.9 & 1.0 & 1.1 & 1.2 \\
$\ldots$ never & 1.0 & 1.1 & 1.2 & 1.3 \\
\hline
\end{tabular}




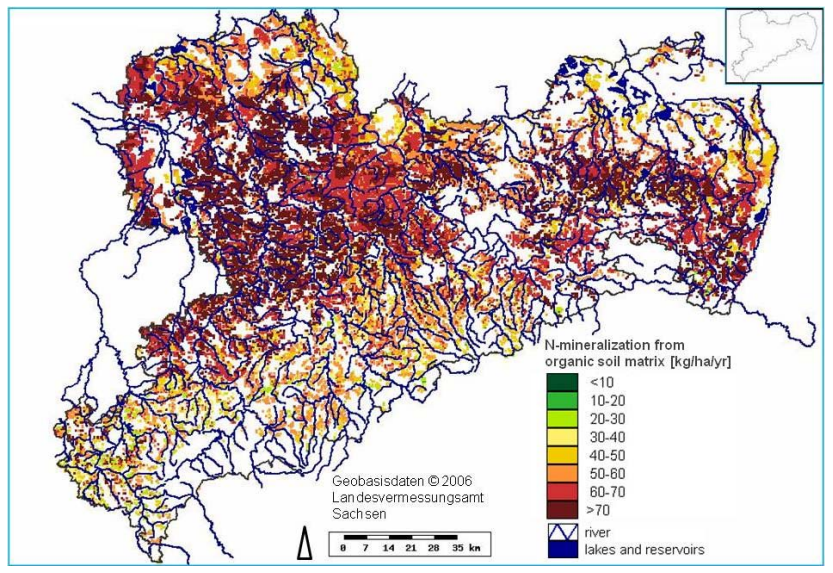

Fig. 4. Mineralization rates from the soil matrix on arable land in Saxony.

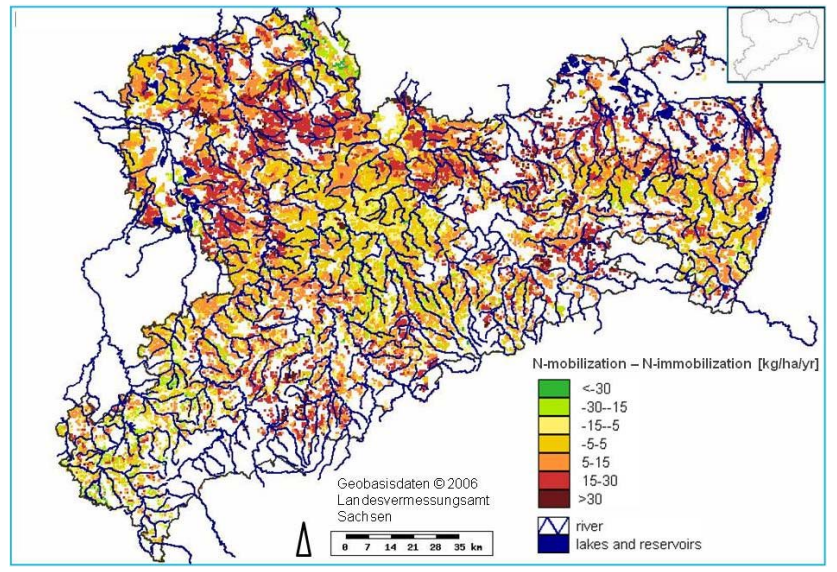

Fig. 5. Results of the function "mobilization - immobilization" from the soil matrix on arable land in Saxony.

detail as well as the derivation of denitrification in topsoil in dependence on the Michaelis-Menten kinetic (according to Wendland, 1992).

\section{Results of the modelling}

The calculated mineralization rates from the organic soil matrix on arable land (average value $60.1 \mathrm{~kg} \mathrm{ha}^{-1} \mathrm{yr}^{-1}$; standard deviation 12.3) are shown in Fig. 4. Mineralization is rather high in the silty hilly loessland in the midlle of Saxony with an intensive agriculture. We have significantly lower rates in the northern lowland parts, caused by poor soils and low percolation rates, as well as in the mountainous region in the south, mainly caused by the lower temperature.

In Fig. 5 the function "mobilization less immobilization" is presented for arable land grids to give an impression to the relationship of both terms. The system seems to be well balanced in the middle and southern parts of Saxony,

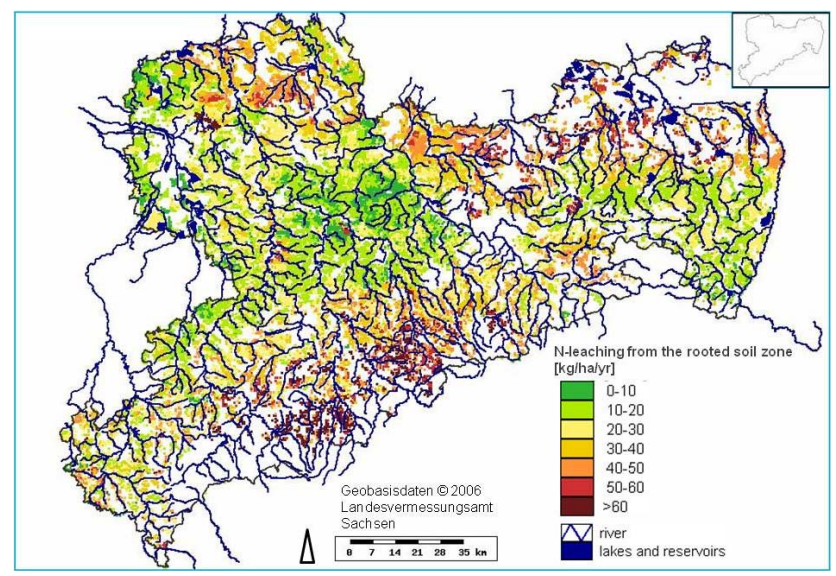

Fig. 6. N-leaching rate from the rooted soil zone on arable land in Saxony.

showing average values of about 5.1 and $4.4 \mathrm{~kg} \mathrm{ha}^{-1} \mathrm{yr}^{-1}$. In contrast to the lower positive or negative values in the loessland, we get significantly higher positive values in the lowland (mean value $12.3 \mathrm{~kg} \mathrm{ha}^{-1} \mathrm{yr}^{-1}$ ) and in some cases in the mountainous region.

The nitrogen leaching from the rooted soil zone (mean value $27.4 \mathrm{~kg} \mathrm{ha}^{-1} \mathrm{yr}^{-1}$; standard deviation 15.7 ) is shown in Fig. 6. As we can see, we have higher rates in the southern and northern parts as compared to lower values in the middle of Saxony.

\section{Discussion}

In order to get an impression of the driving forces of nitrogen leaching in Fig. 6, we have to deal with the nitrogen balance a little bit more detailed. In Fig. 7, we divided the leaching rate into the following components:

1. mobilization - immobilization;

2. fertilization (mineral and organic fertilizer, $\mathrm{N}$-fixing by legumes) - withdrawal (harvest, crop residues being exported);

3. atmospheric deposition;

4. denitrification rate.

According to Fig. 7, the leaching in the lowland region is determined by the higher positive terms (1) and (2), which can be depicted as important nitrogen sources. In the mountainous region, the influence of term (1) is very low, but there is a predominance of term (2) as well as term (3). In the middle region, the terms are low in general.

As we can conclude, the leaching is a function of different terms and depends strongly on regional aspects, which have to be considered in a sustainable management practice. 


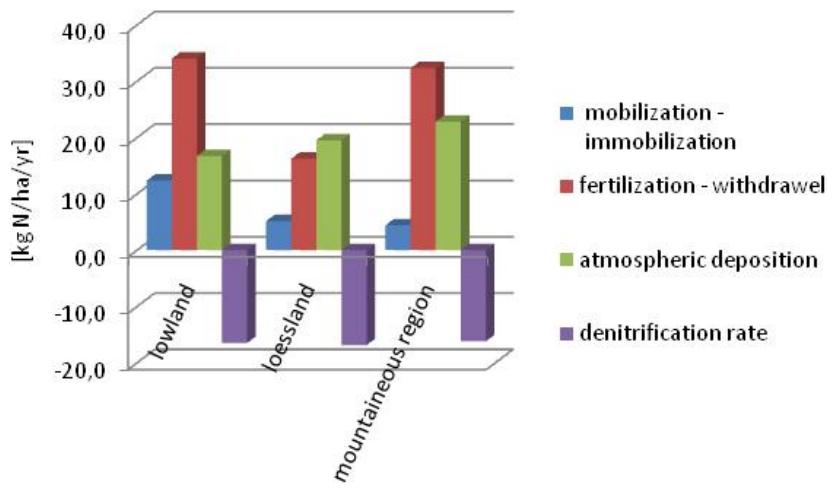

Fig. 7. Driving forces of N-leaching rate and its divisions from the rooted soil zone on arable land in Saxony.

Driving forces may be the relationship of fertilization/withdrawal, the relationship of mobilization/immobilization as well as the atmospheric deposition. Denitrification is an important nitrogen sink in general, whenever the regional differences on this scale are rather small. They might become more important on site scale.

In the STOFFBILANZ model we are able to generate the processes of mobilization and immobilization depending on soil and fruit specific coefficients for cropland sites. Thus we can give an estimation to the status of $\mathrm{N}$-humus (decreasing or increasing) in addition. Focusing on this phenomenon will become more important in the future, because an increasing cultivation of energy crops is quite probable. Effects of special measurements like intercrop cultivation, changes in live-stock or consequences of climate change can be additionally computed in a more sufficient way.

Upscaling site specific parameters, like humus content or C:N-ratio, we have to deal with higher uncertainties especially on the regional scale, which should not be ignored (Mary et al., 1996; Diersch et al., 2008). Thus we have to minimize these uncertainties, doing strong tests of plausibility and validation using the knowledge of agricultural experts. A calibration of parameters like humus content and $\mathrm{C}: \mathrm{N}$-ratio has been done, using literature data from long term experiments and regional soil mapping (Körschens and Schulz, 1999; Düwel et al., 2007; LfUG et al., 2001; Miller et al., 2007). Nevertheless the modelling needs further improvement especially in the lowland region, because we can not exclude that the mineralization intensity is overestimated a little bit. At the moment we are discussing and optimizing the methodology in the framework of research activities supported by the Rural Development Programm (EU), doing microscale modellings with the STOFFBILANZ software in different regions in Saxony. Thereby we will be able to use a more complex database of selected agricultural enterprises.
Acknowledgements. The project "Mapping of nutrient inputs in surface waters in Saxony (Germany)" was supported by Saxon State Agency of the Environment, Agriculture and Geology. We wish to thank all colleagues of the agency for intensive cooperation, support and the supply of agricultural, hydrological, chemical, soil and climate data.

Edited by: A. Wahren, F. Tavares Wahren, and K.-H. Feger Reviewed by: J. Hack and another anonymous referee

\section{References}

Behrendt, H., Kornmilch, M., Opitz, D., Schmoll, O., Scholz, G., and Uebe, R.: Estimation of the nutrient inputs into river systems - experiences from German rivers, Reg. Environ. Change, 3, 107-117, 2002.

Brisson, N., Mary, B., Ripoche, D., Jeuffroy, M. H., Ruget, F., Gate, P., Devienne, F., Antonioletti, R., Durr, C., Nicoullaud, B., Beaudoin, N., Recous, S., Tayot, X., Plenet, D., Richard, G., Cellier, P., Machet, J. M., Meynard, J. M., and Delécolle, R.: STICS: a generic crop simulation model with water and nitrogen balance. Application to wheat and maize. I. Theory and parameterization, Agronomie, 22(1), 69-92, 1998.

Düwel, O., Siebner, C. S., Utermann, J., and Krone, F.: Gehalte an organischer Substanz in Oberböden Deutschlands Bericht über länderübergreifende Auswertungen von Punktinformationen im FISBo BGR, Bundesanstalt für Geowissenschaften und Rohstoffe, 2007 (in German).

Finck, M., Hintemann, T., Reinsch, M., and Otten, I.: Ergebnisse der Modellierung des Nitrataustrags für die gefährdeten Grundwasserkörper Baden-Württembergs, 120. VDLUFA-Kongress in Jena, 16-19 September 2008, Kurzfassungen der Referate, S. 138, 2008 (in German).

Franko, U., Oelschlägel, B., and Schenk, S.: Simulation of temperature-, water- and nitrogen dynamics using the model CANDY, Ecol. Model., 81, 213-222, 1995.

Gebel, M., Halbfaß, S., Bürger, S., Grunewald, K., Kaiser, M., and Uhlig, M.: STOFFBILANZ - Commentary, available at: http: //galf-dresden.de/s1/dl/Stoffbilanz_commentary.pdf (last access: 13 August 2010), 2009.

Halbfaß, S., Gebel, M., and Bürger, S.: Modelling of long term nitrogen retention in surface waters, Adv. Geosci., 27, 145-148, doi:10.5194/adgeo-27-145-2010, 2010.

Halbfaß, S., Gebel, M., Friese, H., Grunewald, K., and Mannsfeld, K.: Atlas der Nährstoffeinträge in sächsische Gewässer, available at: https://publikationen.sachsen.de/bdb/download.do; jsessionid=25291D6B2BB376FE6022FC6292017180.bdb_lb? id=2296290 (last access: 13 August 2010), 2009 (in German).

Henin, S. and Dupuis, M.: Essai de bilan de la matière organique des sols, Ann. Agron., 15(1), 3-29, 1945 (in French).

Kersebaum, K. C., Matzdorf, B., Kiesel, J., Piorr, A., and Steidl, J.: Model-based evaluation of agri-environmental measures in the Federal State of Brandenburg (Germany) concerning N pollution of groundwater and surface water, J. Plant Nutr. Soil Sc., 169, 352-359, 2006.

Körschens, M. and Schulz, E.: Die Organische Bodensubstanz. Dynamik - Reproduktion - ökonomisch und ökologisch begründete Richtwerte, UFZ-Bericht Nr. 13, UFZ Leipzig-Halle GmbH, Halle, 1999 (in German). 
Kunkel, R. and Wendland, F.: WEKU, A GIS-supported stochastic model of groundwater residence times in upper aquifers for the supraregional groundwater management, Environ. Geol., 30, 19, 1997.

Lam, Q. D., Schmalz, B., and Fohrer, N.: Ecohydrological modelling of water discharge and nitrate loads in a mesoscale lowland catchment, Germany, Adv. Geosci., 21, 49-55, doi:10.5194/adgeo-21-49-2009, 2009.

LfUG, LfL, and LAF: Bodenmonitoring in Sachsen, Materialien zum Bodenschutz, Dresden, 2001 (in German).

Mary, B. and Guérif, J.: Intérêts et limites des modèles de prévision de l' évolution des matières organiques et de l'azote dans le sol, Cah. Agric., 3, 247-257, 1994 (in French).

Mary, B., Recous, S., Darwis, D., and Robin, D.: Interactions between decomposition of plant residues and nitrogen cycling in soil, Plant Soil, 181, 71-82, 1996.

Miller, R., Peter, M., and Bräunig, A.: Bodenatlas des Freistaates Sachsen Teil 4: Auswertungskarten zum Bodenschutz Erläuterungsheft, Materialien zum Bodenschutz, LfUG Sachsen (Ed.), 2007 (in German).

Meynard, J. M., Justes, E., Machet, J. M., and Recous, S.: Fertilisation azotée des cultures annuelles de plein champ, in: Maitrise de l'azote dans les agro-systèmes, edited by: Lemaire, G. and Nicolardot, B., Les colloques de l'INRA, Reims, 183199, 1996 (in French).
Schoumans, O. F., Silgram, M., Groenendijk, P., Bouraoui, F., Andersen, H. E., Kronvang, B., Behrendt, H., Arheimer, B., Johnsson, H., Panagopoulos, Y., Mimikou, M., Lo Porto, A., Reisser, H., Le Gall, G., Barr, A., and Anthony, S.G.: Description of nine nutrient loss models: capabilities and suitability based on their characteristics, J. Environ. Monitor., 11, 506-514, 2009.

UBA: Hintergrundpapier zu einer multimedialen StickstoffEmissionsminderungsstrategie, available at: http://www.umweltbundesamt.de/luft/downloads/emissionen/ hg-stickstoffemissionsminderungsstrategie.pdf (last access: 13 August 2010), 2008 (in German).

Uhlig, M., Gebel, M., Halbfaß, S., and Liedl, R.: Mesoskalige Modellierung der grundwasserbürtigen Nitratbelastung von Fließgewässern, Grundwasser, in press, doi:10.1007/s00767010-0141-x, 2010 (in German).

Wendland, F.: Die Nitratbelastung in den Grundwasserlandschaften der "alten" Bundesländer (BRD), Berichte aus der ökologischen Forschung 8, Forschungszentrum Jülich GmbH, Germany, 1992 (in German). 